\section{Response of Container-grown Grapevines to Soil Compaction}

\author{
D.C. Ferree and J.G. Streeter \\ Department of Horticulture and Crop Science, The Ohio State University, Ohio \\ Agricultural Research and Development Center, Wooster, OH 44691
}

Additional index words. leaf nutrients, leaf carbohydrates, photosynthesis, transpiration, Vitis sp.

\begin{abstract}
Container-grown 'Chambourcin' grapevines were exposed to soil compaction created by changing soil bulk density to determine the effect of levels of compaction, rootstocks and moisture stress on mineral nutrition, leaf gas exchange and foliar carbohydrate levels. Shoot growth, leaf area, number of inflorescences and leaf dry weight decreased linearly as soil bulk density increased with the effects being significant above $1.4 \mathrm{~g} \cdot \mathrm{cm}^{-3}$. The early season leaf area was reduced $40 \%$ in the second season, but later leaves were unaffected by a soil bulk density of $1.5 \mathrm{~g} \cdot \mathrm{cm}^{-3}$. Net photosynthesis $(P n)$ and transpiration $(E)$ increased linearly with increasing soil bulk density the first year, but the second year a nonlinear pattern was observed with highest rates at 1.3 and $1.4 \mathrm{~g} \cdot \mathrm{cm}^{-3}$. Soil bulk density of $1.5 \mathrm{~g} \cdot \mathrm{cm}^{-3}$ reduced number of leaves, leaf area and shoot length and advanced bloom 16 days on 'Chambourcin' vines on six rootstocks with no interaction of rootstock and soil compaction. Withholding water for 8 days reduced $P n$ and $E$ in all treatments, with no effect on shoot length, leaf, stem and total dry weights. Moisture stress in the noncompacted soil caused a reduction in leaf concentration of fructose, glucose and myo-inositol, but moisture stress had no effect in the compacted soil. Moisture stress caused a reduction in sucrose in both compacted and noncompacted soil. Compacting soil to a bulk density of $1.5 \mathrm{~g} \cdot \mathrm{cm}^{-3}$ was associated with an increase in leaf $\mathrm{N}, \mathrm{Ca}, \mathrm{Mg}, \mathrm{Al}, \mathrm{Fe}, \mathrm{Mn}, \mathrm{Na}$, and $\mathrm{Zn}$ and a decrease in $\mathrm{P}, \mathrm{K}, \mathrm{B}$, and $\mathrm{Mo}$.
\end{abstract}

Vineyards are costly to establish and once established normally remain productive for many years. Heavy equipment used in cultural practices such as spraying and crop removal travel the same tracks close to the vines many times during the season and over many years will compact the soil. A comprehensive survey of Australian vineyards found that the severity of wheel compaction depended primarily on topsoil texture (Myburgh et al., 1998). They reported that "wheel compaction was encountered in most vineyards visited during this investigation." Sandy and sandy loam soils tend to compact more readily than heavier textured soils such as loams or clays and wet soils were found to aggravate compaction.

Soil compaction increases the bulk density and mechanical impedance of the soil and reduces soil conductivity, permeability, and diffusivity to water and air (Vepraskas, 1994). Effects of compaction on annual plants include restriction of root growth, decreased shoot growth, leaf area development, dry matter production, yield and stomatal conductance (Andrade et al., 1993; Brereton et al., 1986; Gross, 1977). The study of the effects of soil compaction on woody perennial crops is more limited, but negative effects on growth have been reported for conifer seedlings in a loam soil above a bulk density of $1.78 \mathrm{~g} \cdot \mathrm{cm}^{-3}$ (Conlin and van den Driessche, 1996), container ornamentals in a silt loam above $1.75 \mathrm{~g} \cdot \mathrm{cm}^{-3}$ bulk

Received for publication12 Mar. 2003. Accepted for publication 31 Dec. 2003. Salaries and research support provided by state and federal funds appropriated to the Ohio Agricultural Research and Development Center, The Ohio State University. The authors gratefully acknowledge the help of David Scurlock and John Schmid with these projects and the Ohio Grape Industries Program for partial financial support. density (Maupin and Struve, 1997) and apple (Malus $\times$ domestica) above a bulk density of $1.40 \mathrm{~g} \cdot \mathrm{cm}^{-3}$ in a silt clay (Slowik, 1970) or silt loam (Ferree et al., 2003).

For grapes, Van Huyssteen (1989) studied the effect of soil compaction and found that grapevine root growth decreased linearly beginning at a bulk density of $1.4 \mathrm{~g} \cdot \mathrm{cm}^{-3}$ in several soils high in sand. Soil texture markedly influenced the degree of the response. In a container study he found that although the penetrating ability of grapevine roots declined as bulk density increased, there was no critical value above which root penetration was abruptly curtailed. Grapevines did not show compensatory growth of roots in loose topsoil as a result of restriction due to compaction in the subsoil.

Penkov et al. (1979) reported that grapevine roots readily penetrated soils with bulk densities of 1.0 to $1.2 \mathrm{~g} \cdot \mathrm{cm}^{-3}$, but penetration decreased sharply at values greater than $1.5 \mathrm{~g} \cdot \mathrm{cm}^{-3}$ (soil type was not specified). The objectives of the present series of studies were to determine theinfluence of soil compaction of a silt loam soil similar to many soils where grapes are grown in the midwestern U.S. on growth and development of containergrown 'Chambourcin' vines and to evaluate the interaction of rootstocks and soil moisture stress on the influence of soil compaction.

\section{Materials and Methods}

Level of compaction. Newly rooted 'Chambourcin' vines were grown fromApril-November in 0.84 -L containers in a medium of equal parts of peat, perlite, and soil. The vines were moved to a refrigerated $\left(7.0^{\circ} \mathrm{C}\right)$ storage until removed 11 Feb. 11, 1999. The medium was washed from the roots and all roots trimmed to a length of 10 $\mathrm{cm}$. Vines were planted in 5.6-L containers in Orrville silt loam soil (fine-loamy, mixed, active, nonacid, mesicAerics fluvaquent; $20 \%$ sand, $62 \%$ silt, $18 \%$ clay). The same soil was used in all studies described in this paper and was collected from a pile created from the top $30 \mathrm{~cm}$ of a field. After thoroughly mixing, the soil was placed in the containers in $2 \mathrm{~cm}$ lifts and compressed with a mallet to establish bulk densities of 1.0 (Control-not compacted), 1.2, 1.3, 1.4, and 1.5 $\mathrm{g} \cdot \mathrm{cm}^{-3}$. A $2 \mathrm{~cm}$ layer of washed pea gravel was placed on the container surface to reduce surface evaporation. Greenhouse temperatures were $21 \pm$ $3^{\circ} \mathrm{C}$ day, $15 \pm 3{ }^{\circ} \mathrm{C}$ night and water was applied by weighing representative containers regularly and returning the container to its saturated weight by submerging it for $\approx 4 \mathrm{~h}$. Vines were trained to a single shoot supported by a pole with laterals removed weekly. Treatments were arranged on the greenhouse bench as a randomized complete block with 10 replications. On 8 June 1999, after 117 days in the greenhouse, vines in four replications were harvested and divided into leaves, shoot, trunk and roots and placed in a drying oven at $70{ }^{\circ} \mathrm{C}$. The remaining six replications were grown another $30 \mathrm{~d}$ in the greenhouse and then placed in refrigerated storage at $7{ }^{\circ} \mathrm{C}$, returned to the greenhouse 3 Jan. 2000, when vines were pruned back to three buds. Inflorescences were counted on all three shoots at about stage 15 (Eichhorn and Lorenz, 1977) and then the longest shoot with a good cluster retained and the others removed. The vines were managed as previously described.

Shoot length was measured weekly and the area of the fourth leaf from the base was calculated by measuring length and width every 3 to $7 \mathrm{~d}$ and using the following formula: area $=1.55+0.009368 \times(\mathrm{L} \times \mathrm{W})$. The formula was derived from determining the area of 100 'Chambourcin' leaves of various sizes on a leaf area meter $\left(R^{2}=0.99\right)($ LI-COR, Lincoln, Nebr.). When the four replications were harvested, total leaf area was measured (LI-300; LI-COR) and a soil penetrometer(Investigator Soil Compaction Meter, Spectrum Technologies, Inc., Plainfield, Ill.) recorded measurements at 5-cm depths in the containers.

Net photosynthesis (Pn) and transpiration(E) were measured beginning at 9:30 a.m. after saturating the soil on 11 May 1999 and measured 7 d later at the same time of day without additional moisture applied. The vines were watered and measurements taken $3 \mathrm{~d}$ later. Measurements were made on the eighth leaf from the base with a portable infrared gas analyzer equipped with a $6.25 \mathrm{~cm}^{2}$ leaf chamber (model LCA2; Analytical Development Co., Hodesdon, U.K.). Air flow was regulated at $300 \mathrm{~mL} \cdot \mathrm{min}^{-1}$, with an air portal outside the greenhouse. Ambient $\mathrm{CO}_{2}$ concentration, humidity of the air entering and leaving the leaf chamber, the chamber temperature and incidence of photosynthetically active radiation (PAR) were recorded with each measurement. Toincrease ambient greenhouse light, each vine was moved under a fixture containing two GE Lucalux 400-W bulbs. The light level at the leaf chamber averaged $1180 \mathrm{~mol} \cdot \mathrm{m}^{-2} \cdot \mathrm{s}^{-1}$ with no values below $700 \mathrm{~mol} \cdot \mathrm{m}^{-2} \cdot \mathrm{s}^{-1}$.

Rootstock compaction. 'Chambourcin' vines on the following rootstocks were purchased from a commercial nursery: own rooted, 3309C, 5C, $18-815, \mathrm{SO} 4$, and 1616E. Roots on all vines were 
cut to $10 \mathrm{~cm}$ and vines planted in containers as previously described with soil at a bulk density of $1.0 \mathrm{~g} \cdot \mathrm{cm}^{-3}$ (control) or compacted to $1.5 \mathrm{~g} \cdot \mathrm{cm}^{-3}$. The vines were arranged on the greenhouse bench as a randomized complete block with treatments arranged as a two (bulk density) by six (rootstocks) factorial with six single-vine replications. Vines were cut to the basal three buds and the most vigorous shoot with a single cluster was selected and trained as a single shoot with laterals removed as they developed. The length and width of the fourth leaf was measured at 3- to 4-d intervals until it was fully expanded and area calculated using the formula previously described. Shoot length was measured each week and date of bloom recorded.

The vines were moved to a refrigerated storage in September and allowed to defoliate naturally and returned to the greenhouse on 3 Jan. 2000. The vines were cut back to three buds as previously described, and three shoots left to develop until inflorescences could be counted and then the strongest shoot was selected and all but one cluster removed. The area of the third and eighth leaf on this shoot were measured as previously described. Shoot length was measured weekly until the experiment was terminated 1 Mar. 2000.

Compaction plus short-termmoisture stress. On 1 June 2001, medium was washed from the roots of own rooted 'Chambourcin' vines that

Fig. 1. Influence of increasing levels of soil compaction (bulk density) on (A) average shoot length and (B) area of the fourth leaf from the base of own-rooted 'Chambourcin' grapevines grown in containers.
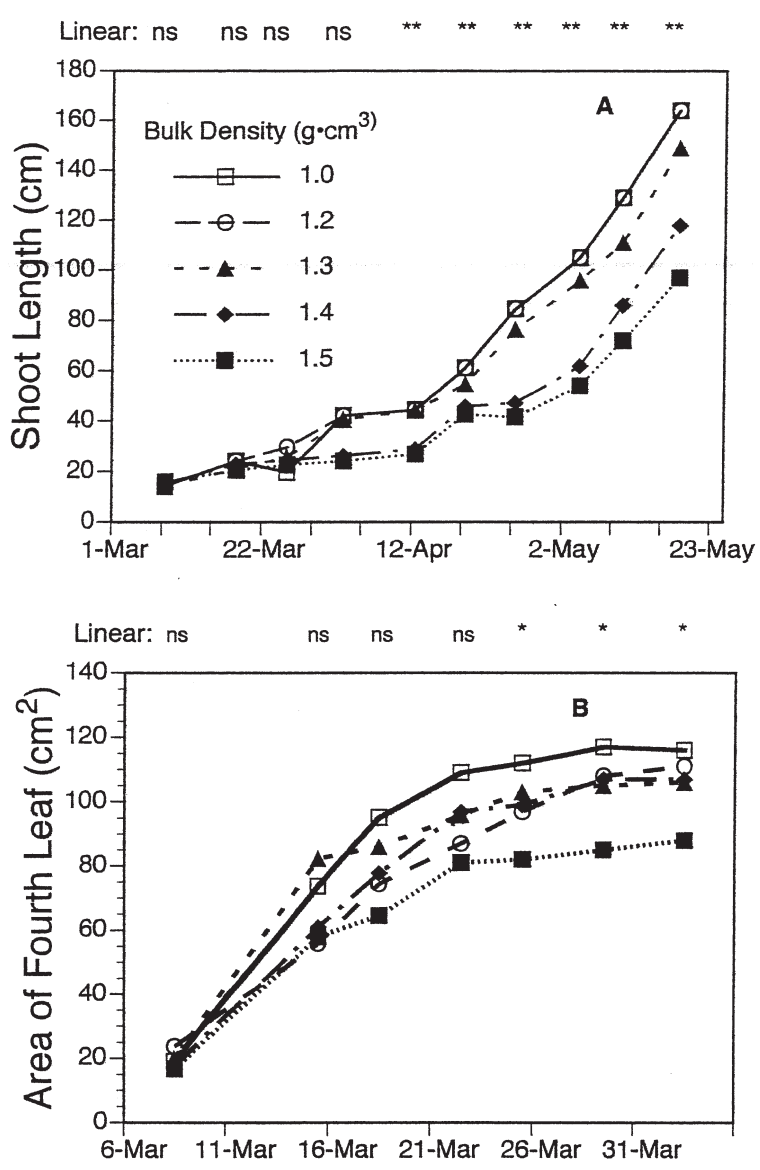

had previously been grown in 5.6-L containers in a medium of equal units of soil, peat and perlite for two years and all roots cut to $10 \mathrm{~cm}$. The vines were planted as previously described in soil with bulk densities of $1.0 \mathrm{~g} \cdot \mathrm{cm}^{-3}$ (control) or $1.5 \mathrm{~g} \cdot \mathrm{cm}^{-3}$ (compacted). On 31 July 2001, the soil in the containers was saturated by submersion for $4 \mathrm{~h}$ in water and no further water was provided to half of the vines. A randomized complete block design with treatments arranged as a two $2 \times 2$ factorial where bulk densities of 1.0 or $1.5 \mathrm{~g} \cdot \mathrm{cm}^{-3}$ by watered control or moisture stress were the independent variables with five replications and two vines of each treatment in each replication.

Pn and E were measured on the most recent fully expanded leaf as previously described before and eight days after water was withheld. Following measurement of Pn andE, the leaf was removed, immediately frozen at $-20^{\circ} \mathrm{C}$. The tissue was freeze-dried and ground using a Wiley mill to pass a 20-mesh screen and ground tissue was stored in tightly sealed vials at room temperature. Dried, ground tissue was simultaneously extracted and derivatized for analysis of carbohydrates by gas liquid chromatography using an automated injector as described by Streeter and Strimbu (1998). Because the use of an internal standard gives high precision in these analyses, each sample was analyzed only once.

The vines were harvested 10 Aug. 2001, and tissue divided into leaves, petioles, stem, rootstocks and roots and dried at $70{ }^{\circ} \mathrm{C}$ in a forced-draft oven. The dried petioles were ground through a 20-mesh screen and submitted to the Ohio State University STAR Laboratory for nutrient analysis using an inductively coupled plasma (ICP) spectrophotometer (Watson and Isaac, 1990).

\section{Results}

Level of compaction. Shoot growth of 'Chambourcin' vines decreased linearly as soil bulk density increased (Fig. 1A) with the effects being significant above $1.4 \mathrm{~g} \cdot \mathrm{cm}^{-3}$. The effects of increasing levels of bulk density became more pronounced as the season progressed. A similar pattern occurred in the development of the fourth leaf from the base of the shoot (Fig. 1B). Harvest of four replications of the vines showed a linear reduction in dry weight of canes and leaves as soil bulk density increased and this also resulted in a linear decline in total dry weight (Table 1). Dry weight of the trunk and roots were not influenced by increasing levels of soil bulk density.

When the remaining vines were grown a second season, leaf area of the third leaf from the base was linearly reduced as soil bulk density increased (Table 1). There was a $25 \%$ difference the first year between leaf area of vines in bulk densities of 1.0 and $1.5 \mathrm{~g} \cdot \mathrm{cm}^{-3}$ and this difference increased to $40 \%$ in the second year. However, development of later leaves (eighth from the base) or total number of leaves was not influenced by soil bulk density. Measurement of shoot length early in the growth phase (31 Jan. 2000) showed a linear decrease with increasing levels of bulk density, but later (1 Mar. 2000) there was no effect on shoot length. The total number of inflorescences on three shoots was linearly reduced with increasing levels of soil bulk density. Of the three shoots initially left to determine the effect on inflorescence development, the basal shoot had the fewest and the apical the most inflorescences except for vines in soil bulk density of $1.4 \mathrm{~g} \cdot \mathrm{cm}^{-3}$ where the three shoots had equal numbers.

The effects of increasing levels of soil bulk density on Pn and E did not follow a consistent pattern (Table 2). During the first year there was a significant linear increase in Pn with increasing levels of soil bulk density in well watered conditions (11 May 1999) and following $7 \mathrm{~d}$ of withholding moisture (18 May 1999), but the reverse trend occurred in 21 May 1999 after the vines had been watered following Pn measurements on 18 May 1999. During the second year rates of Pn were higher and a significant quadratic pattern occurred with the highest rates on vines grown in soils with bulk densities of 1.3 and 1.4 $\mathrm{g} \cdot \mathrm{cm}^{-3}$ and a significant decline at a bulk density of $1.5 \mathrm{~g} \cdot \mathrm{cm}^{-3}$. Withholding water for $5 \mathrm{~d}$ caused a dramatic reduction in Pn with no influence of the different levels of soil bulk density. Transpiration (E) was generally not affected by the different levels of soil bulk density (data not presented).

Rootstock compaction. To determine if rootstocks responded differently to soil compaction, 'Chambourcin' on six rootstocks were grown in containers with soil at $1.0 \mathrm{~g} \cdot \mathrm{cm}^{-3}$ bulk density (noncompacted) and $1.5 \mathrm{~g} \cdot \mathrm{cm}^{-3}$ (compacted). There was no interaction between bulk density and rootstock for any measure of growth during the first year (Table 3). Soil bulk density of 1.5 $\mathrm{g} \cdot \mathrm{cm}^{-3}$ reduced number of leaves, leaf area and shoot length of 'Chambourcin' vines over the growing season. Bloom was advanced by $16 \mathrm{~d}$ on vines grown in compacted soil. Differences in 'Chambourcin' vine growth due to rootstocks were small. Although vines on SO4 tended to be smaller, vines on several other rootstocks were similar for each growth measurement. Results for vine growth the second year were very similar to results in the first year (Table 4). The interaction between soil compaction and rootstock for total inflorescences was significant (Fig. 2). Soil bulk density of $1.5 \mathrm{~g} \cdot \mathrm{cm}^{-3}$ caused a significant reduction in inflorescences on the following rootstocks: own rooted, 3309C, 18815 , and SO4. There was no effect of $1.5 \mathrm{~g} \cdot \mathrm{cm}^{-3}$ soil bulk density on inflorescence development on 'Chambourcin' vines on 5C or 1616E. Time of bud burst was not affected by soil bulk density or rootstock (data not presented).

Compaction plus short-term moisture stress. Soil bulk density of $1.5 \mathrm{~g} \cdot \mathrm{cm}^{-3}$ again caused a significant reduction in shoot length of own rooted 'Chambourcin' vines (Fig. 3). Withholding water for eight days had no influence on shoot growth (data not shown). Under well-watered conditions vines growing in soil 
Table 1. Influence of increasing levels of soil bulk density on dry weight distribution of own rooted 'Chambourcin' grapevines at the end of the first growing season ${ }^{\mathrm{z}}$ and growth and flowering in the second season.

\begin{tabular}{|c|c|c|c|c|c|c|c|}
\hline \multirow{3}{*}{$\begin{array}{l}\text { Bulk } \\
\text { density } \\
\left(\mathrm{g} \cdot \mathrm{cm}^{-3}\right)\end{array}$} & \multirow{3}{*}{$\begin{array}{c}\text { Total } \\
\text { leaf } \\
\text { area } \\
\left(\mathrm{cm}^{2}\right)\end{array}$} & & & & \multicolumn{3}{|c|}{ Second growing season } \\
\hline & & \multicolumn{3}{|c|}{$\begin{array}{c}\text { Dry wt (g) } \\
\text { distribution }\end{array}$} & \multicolumn{2}{|c|}{$\begin{array}{c}\text { Leaf area } \\
\left(\mathrm{cm}^{2}\right)\end{array}$} & \multirow{2}{*}{$\begin{array}{c}\text { Total } \\
\text { inflorescences } \\
(3 \text { shoots })\end{array}$} \\
\hline & & Cane & Leaves & Total & $3 r d$ & 8 th & \\
\hline 1.0 & 3877 & 20.3 & 21.5 & 77.8 & 301 & 277 & 2.83 \\
\hline 1.2 & 3579 & 21.8 & 23.1 & 85.0 & 243 & 252 & 3.83 \\
\hline 1.3 & 2757 & 13.0 & 15.5 & 65.6 & 287 & 233 & 1.66 \\
\hline 1.4 & 1920 & 6.8 & 8.9 & 43.3 & 149 & 246 & 2.40 \\
\hline 1.5 & 2340 & 9.2 & 12.2 & 58.7 & 179 & 241 & 0.14 \\
\hline Linear & $* *$ & $* *$ & $* *$ & $* *$ & $*$ & NS & $* *$ \\
\hline Quadratic & NS & NS & NS & NS & NS & NS & $*$ \\
\hline
\end{tabular}

${ }^{\text {z} F o u r ~ r e p l i c a t i o n s ~ w e r e ~ h a r v e s t e d ~ a f t e r ~} 117 \mathrm{~d}$ of growth on 8 June 1999.

'Trunk and root dry weight were not significant.

Ns, ${ }^{* * *}$ Nonsignificant or significant at $P \leq 0.05$ or 0.01 , respectively.

Table 2. Influence of increasing levels of soil bulk density on net photosynthesis $\left(\mathrm{Pn} ; \mathrm{mol} \cdot \mathrm{m}^{-2} \cdot \mathrm{s}^{-1} \mathrm{of} \mathrm{CO}_{2}\right)$ of own rooted 'Chambourcin' grapevines.

\begin{tabular}{|c|c|c|c|c|c|}
\hline \multirow{3}{*}{$\begin{array}{l}\text { Bulk } \\
\text { density } \\
\left(\mathrm{g} \cdot \mathrm{cm}^{-3}\right)\end{array}$} & \multicolumn{5}{|c|}{$\mathrm{Pn}$} \\
\hline & \multicolumn{3}{|c|}{1999} & \multicolumn{2}{|c|}{2000} \\
\hline & $11 \mathrm{May}^{\mathrm{z}}$ & 18 May & 21 May & 2 Feb. & 7 Feb. \\
\hline 1.0 & 5.79 & 2.15 & 5.66 & 14.13 & 4.14 \\
\hline 1.2 & 8.08 & 3.65 & 8.23 & 14.02 & 2.06 \\
\hline 1.3 & 7.19 & 3.13 & 4.24 & 15.85 & 6.48 \\
\hline 1.4 & 11.36 & 6.48 & 4.27 & 15.58 & 6.21 \\
\hline 1.5 & 8.90 & 5.88 & 3.73 & 8.57 & 3.30 \\
\hline Linear & $* *$ & $* *$ & $* *$ & $*$ & NS \\
\hline Quadratic & NS & NS & $*$ & $* *$ & NS \\
\hline
\end{tabular}

${ }^{2}$ Soil saturated on 11 May 1999, 21 May 1999, and 2 Feb. 2000.

NS, **** Nonsignificant or significant at $P \leq 0.05$ or 0.01 , respectively.

compacted to a bulk density of $1.5 \mathrm{~g} \cdot \mathrm{cm}^{-3}$ had lower Pn and E (data not presented). However, after withholding water for $8 \mathrm{~d} \mathrm{Pn}$ and $\mathrm{E}$ were reduced in all treatments, but leaves from vines in the compacted soil had higher rates of both $\mathrm{Pn}$ and $\mathrm{E}$. The moisture stress resulted in a greater reduction in Pn and $\mathrm{E}$ than soil compaction, but there was no interaction between compaction and moisture stress. Water loss from the container was estimated by weighing each container after watering on 31 July 2001 and following the stress and showed that moisture loss was much lower in compacted soil compared to noncompacted. As expected, withholding moisture resulted in a greater moisture loss but there was no interaction between soil compaction and stress on moisture loss. Leaf and stem dry weight of the vines were decreased when grown in a soil with $1.5 \mathrm{~g} \cdot \mathrm{cm}^{-3}$ bulk density and this also caused a $18 \%$ reduction in total dry weight (Table 5). The short (8-d) moisture stress did not cause reductions in dry weight of any of the tissues.

Compacting soil by increasing bulk density to $1.5 \mathrm{~g} \cdot \mathrm{cm}^{-3}$ resulted in an increase in petiole concentration of the following elements: $\mathrm{N}$, $\mathrm{Ca}, \mathrm{Mg}, \mathrm{Al}, \mathrm{Fe}, \mathrm{Mn}, \mathrm{Na}$, and $\mathrm{Zn} . \mathrm{P}, \mathrm{K}, \mathrm{B}$, and Mo were decreased in compacted soil. The interaction between soil compaction and moisture stress for petiole $\mathrm{N}$ occurred because moisture stress had no effect in noncompacted soil, but resulted in a $20 \%$ increase in leaf $\mathrm{N}$ in compacted soil. All leaf concentrations of nutrient elements were in the sufficient range, except $\mathrm{Fe}$, which was below the 30 to $50 \mathrm{ppm}$ range considered sufficient (Cahoon, 1985). However, no Fe deficiency symptoms were evident on the leaves. The significant interaction with B occurred because compaction caused a reduction in petiole $B$ below the sufficient range with no effect of moisture stress. However, in noncompacted soil moisture stress resulted in an increase from $29 \mathrm{ppm} \mathrm{B}$ in the control to 33 $\mathrm{ppm}$ in the vines under moisture stress.

A significant interaction occurred between soil compaction and moisture stress for all the leaf carbohydrates except sucrose (Table 6). The interaction occurred because moisture stress in the noncompacted soil resulted in a reduction in fructose, glucose and myo-inositol, but stress had noeffect in the compacted soil. Myo-inositol was higher in vines grown in compacted soil compared to noncompacted soil. Moisture stress was associated with a reduction in sucrose in both compacted and noncompacted soil. An unknown compound in grape leaves was affected by treatments but could not be identified by trial and error matches to known compounds. The compound is probably a four-carbon compound. It would have one or more hydroxyl groups because of the derivatization chemistry used for analysis. Analysis of the known compounds erythrose, erythritol, threitol, arabitol, xylitol and-hydroxybutyric acid did not provide a match with the unknown. Moisture stress had no effect on the leaf concentration of the unknown in the noncompacted soil, but resulted in an increase in compacted soil. This response was different than for the other known carbohydrates.

Soil penetrometer values taken as the plants were harvested in the level of compaction study and in the compaction short term moisture stress study show an increase in penetrometer soil resistance with increased bulk density (Table 7).

\section{Discussion}

To relate the created soil bulk densities used in this series of studies to the more easily measured penetrometer values often used in the field, penetrometer readings were made on the soil in the pots of two studies. Generally as soil bulk density increased, penetrometer values also increased and the linear effect was significant (Table 7). However, a mean separation test shows that many of the levels could not be clearly differentiated statistically due to the rather large variation in the penetrometer

Table 3. Influence of soil bulk density and rootstocks on growth of 'Chambourcin' grapevines during the first year of growth in containers.

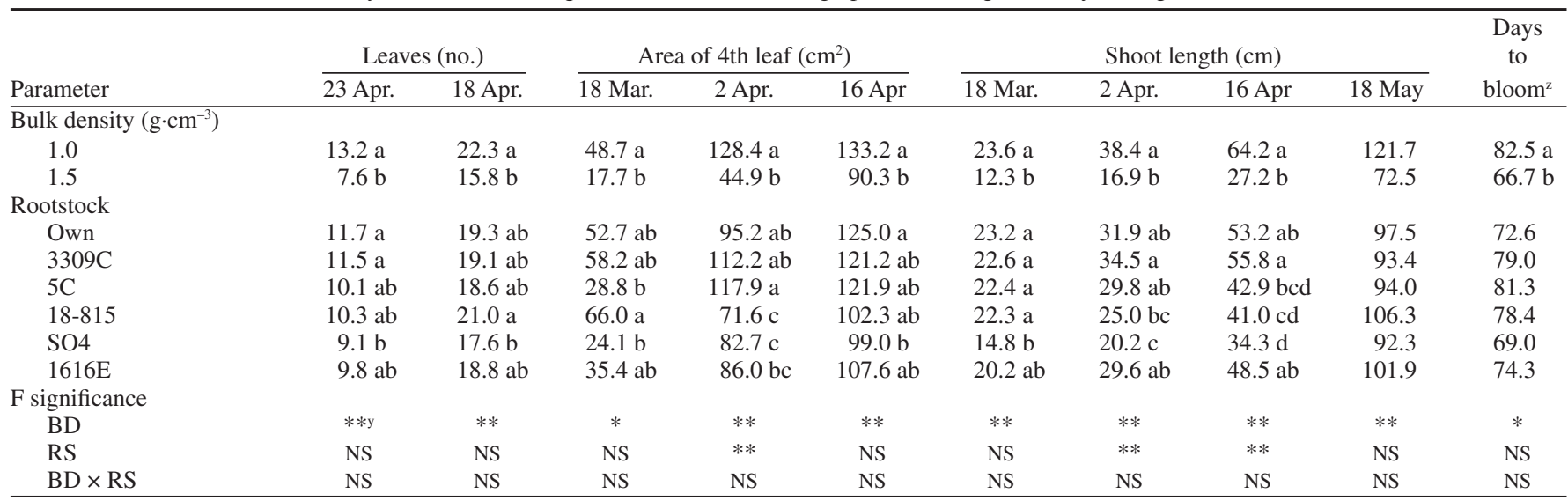

${ }^{2}$ Days to full bloom beginning $11 \mathrm{Feb} .1999$ when placed in greenhouse.

Ns, ,***Nonsignificant or significant at $P \leq 0.05$ or 0.01 , respectively. 
Table 4. Influence of soil bulk density and rootstocks on growth of 'Chambourcin' grapevines in the second year of growth in the containers.

\begin{tabular}{|c|c|c|c|c|c|}
\hline \multirow[b]{3}{*}{ Parameter } & \multicolumn{3}{|c|}{1 Mar. 2000} & & \\
\hline & \multirow{2}{*}{$\begin{array}{c}\text { Leaf } \\
\text { no. }\end{array}$} & \multicolumn{2}{|c|}{ Leaf area $\left(\mathrm{cm}^{2}\right)$} & \multicolumn{2}{|c|}{ Shoot length (cm) } \\
\hline & & $3 \mathrm{rd}$ & 8th & 31 Jan. & 1 Mar. \\
\hline \multicolumn{6}{|c|}{ Bulk density $\left(\mathrm{g} \cdot \mathrm{cm}^{-3}\right)$} \\
\hline 1.0 & $21.0 \mathrm{a}$ & $321 \mathrm{a}$ & $296 \mathrm{a}$ & $83.6 \mathrm{a}$ & $201 \mathrm{a}$ \\
\hline 1.5 & $18.2 \mathrm{~b}$ & $269 \mathrm{~b}$ & $260 \mathrm{~b}$ & $66.4 \mathrm{~b}$ & $171 \mathrm{~b}$ \\
\hline \multicolumn{6}{|l|}{ Rootstock } \\
\hline Own & $19.8 \mathrm{ab}$ & 283 & 302 & $81 \mathrm{ab}$ & 199 \\
\hline $3309 \mathrm{C}$ & $20.3 \mathrm{a}$ & 363 & 286 & $83 \mathrm{ab}$ & 190 \\
\hline $5 \mathrm{C}$ & $20.5 \mathrm{a}$ & 281 & 268 & $74 \mathrm{abc}$ & 177 \\
\hline $18-815$ & $20.0 \mathrm{a}$ & 287 & 265 & $89 a$ & 206 \\
\hline $\mathrm{SO} 4$ & $17.3 \mathrm{~b}$ & 275 & 255 & $51 \mathrm{c}$ & 160 \\
\hline $1616 \mathrm{E}$ & $19.0 \mathrm{ab}$ & 280 & 287 & $61 \mathrm{bc}$ & 176 \\
\hline \multicolumn{6}{|l|}{ F significance } \\
\hline $\mathrm{BD}$ & $* *$ & $* *$ & $* *$ & $* *$ & $* *$ \\
\hline RS & $*$ & NS & NS & $* *$ & NS \\
\hline $\mathrm{BD} \times \mathrm{RS}$ & NS & $*$ & NS & NS & NS \\
\hline
\end{tabular}

Ns,*,**Nonsignificant or significant at $P \leq 0.05$ or 0.01 , respectively.

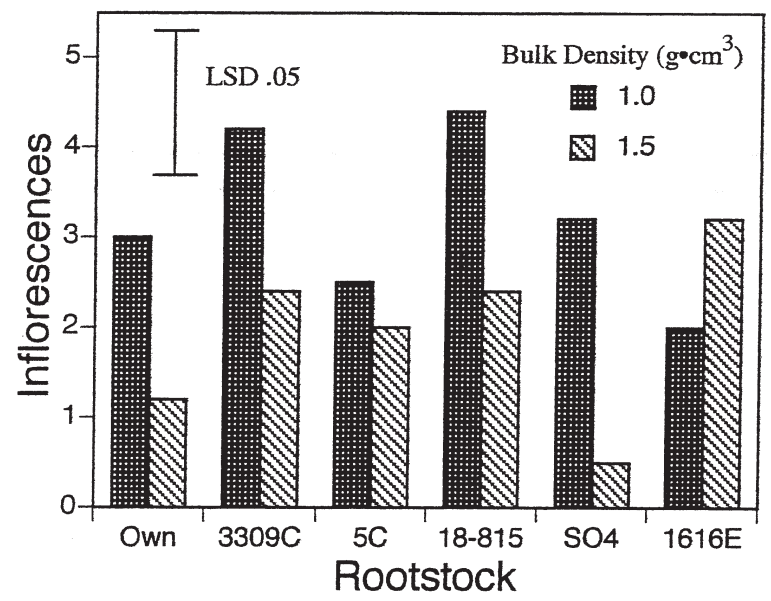

penetration resistance where "apparently grapevine roots cannot readily penetrate soil." Penkov et al. (1979) found that grapevine roots did not readily penetrate soils with bulk densities above $1.5 \mathrm{~g} \cdot \mathrm{cm}^{-3}$ and reductions in growth occurred. These findings appear to correspond well to the penetration values we measured in soil bulk densities of 1.4 or $1.5 \mathrm{~g} \cdot \mathrm{cm}^{-3}$ where significant reduction in growth occurred. Van Huyssteen (1989) found a high correlation between bulk density and penetrometer values. However Van Huyssteen (1989) reported "no critical bulk density

Fig. 2. Interaction of soil compaction (bulk density) and rootstock on inflorescences of "Chambourcin' grapevines grown in containers.

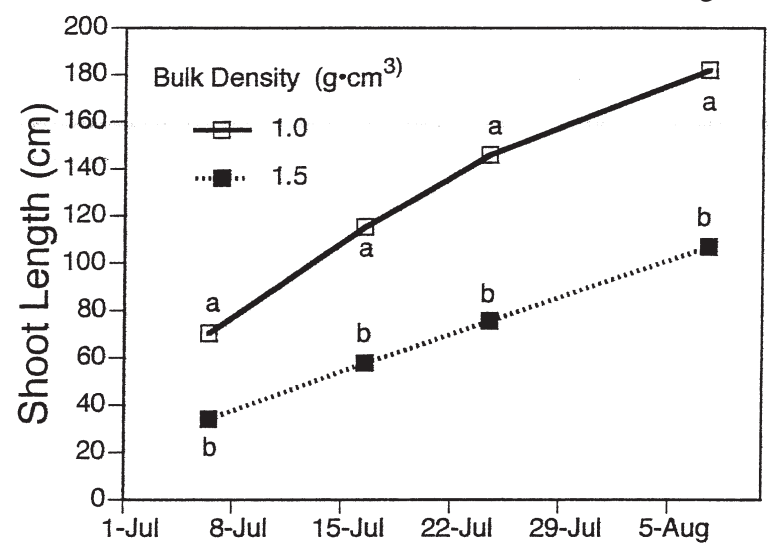

or penetrometer soil strength for the impedance of grapevine roots. Roots were found in the pot experiment for any of the five different soils investigated. However, above ground grapevine performance decreased linearly with increasing subsoil bulk densities." Roots were found in both greenhouse and field studies in soil with bulk density or penetrometer values that impeded growth. Results of our studies also show a good relationship as bulk density and penetrometer values increase top growth decreases, but root growth (Table 1) was not affected.

Soil compaction by increasing soil bulk density to 1.4 or $1.5 \mathrm{~g} \cdot \mathrm{cm}^{-3}$ consistently reduced shoot length and leaf area in this

Fig. 3. Influence of soil compaction of $1.5 \mathrm{~g} \cdot \mathrm{cm}^{-3}$ bulk density on shoot growth of own-rooted 'Chambourcin' grapevines over the season. Mean separation by Duncans multiple range $P=0.05$.

readings. These variations are likely due to the speed and consistency of speed of inserting the probe and to the moisture content of the soil. The instrument used was a hand-inserted portable field instrument and it was not possible to insert it at a constant rate as it would an automatic instrument inserted hydraulically. Myburgh et al. (1998) used $2000 \mathrm{Kpa}$ as the explain the large effect on shoot and leaf growth. Van Huyssteen (1989) found large differences among four soil textures (69\% to 89\% sand, $5 \%$ to $15 \%$ silt, and $7 \%$ to $17 \%$ clay) on the effect of increasing bulk density on root development. Compaction of the soil (20\% sand, $62 \%$ silt, $18 \%$ clay) used in these studies had minimal effect on root growth in this study and in a series of studies on apple (Ferree et al., 2003).

Bulk densities of different soil types cannot be directly compared because the compaction level varies with soil type. It is interesting that the grapevines in these studies appear to be similar or slightly more sensitive than other woody plant species in their response to the level of soil compaction necessary to reduce growth. Growth of red oak (Quercus rubra L.) was not influenced by $1.5 \mathrm{~g} \cdot \mathrm{cm}^{-3}$ but was reduced at $1.75 \mathrm{~g} \cdot \mathrm{cm}^{-3}$ (silt loam: $25 \%$ sand, $60 \%$ silt, $15 \%$ clay) (Maupin and Struve, 1997). Compaction above $1.7 \mathrm{~g} \cdot \mathrm{cm}^{-3}$ decreased needle length and root dry weight of pine (Pinus contorta) (loam: $46 \%$ sand, $47 \%$ silt, $7 \%$ clay) (Conlin and van den Driessche, 1996). Studies on apple indicate little effect below $1.4 \mathrm{~g} \cdot \mathrm{cm}^{-3}$ but growth reduction at $1.5 \mathrm{~g} \cdot \mathrm{cm}^{-3}$ in the same soil used in these studies and this agrees with studies on apple by Slowik (1970) (heavy soil, but texture not specified) and (silt loam: $20 \%$ sand, $62 \%$ silt, $18 \%$ clay) (Ferree et al., 2003).

Since rootstocks influence growth of grapevines and vary in their adaptability to soils, it was hoped that some may tolerate compacted soils better than others. However, in the study comparing own rooted vines with vines on five rootstocks that have performed well under eastern conditions (Ferree etal., 1996) no differences in growth occurred as growth on all rootstocks was reduced in compacted soil (Tables 4 and 5). Apple rootstocks did respond differently to the influence of soil compaction on growth (Ferree et al., 2003; Slowik, 1970).

One of the unexpected results was that although soil compaction had major effects on plant growth, the effects on Pn and E were small or inconclusive suggesting that carbon or moisture supply were not major factors limiting growth. Increasing levels of soil compaction increased Pn (Table 2) and in the other study a bulk density of $1.5 \mathrm{~g} \cdot \mathrm{cm}^{-3}$ caused a $15 \%$ decrease in Pn under well watered conditions and a $28 \%$ increase in Pn when water was withheld for eight days (data not presented). Reports on the effect of soil compaction on wheat (Triticum aestivum L.) (Masle and Farquhar, 1988) and sunflower (Helianthus annuL.) (Andrade etal., 1993) show that the rate of Pn was equal to or, in some cases, higher in plants in compacted soil compared to plants growing in noncompacted soil even though total photosynthetic leaf area had been reduced by soil compaction. However, Pn of Pinus contorta was decreased by soil compaction (Conlin and van den Driessche, 1996).

Since leaf concentrations of several nutrient elements were increased in vines growing in compacted soils nutrient uptake was unlikely the cause of the growth reduction due to soil compaction (Table 5): N, Ca, Mg, Fe, Mn, Na, and Zn. Nutrient uptake from apple trees in a compaction study in the same soil used in this study differed with decreases in many of the above elements and 
Table 5.Influence of soil bulk density and short-term moisture stress on dry weight (DW) distribution and leaf nutrient element concentrations of 'Chambourcin' grapevines.

\begin{tabular}{|c|c|c|c|c|c|c|c|c|c|c|c|c|c|c|c|}
\hline \multirow[b]{2}{*}{ Parameter } & \multicolumn{3}{|c|}{ DW distribution $(\mathrm{g})^{\mathrm{z}}$} & \multicolumn{5}{|c|}{ Major elements (\% DW) } & \multicolumn{7}{|c|}{ Minor elements (ppm) } \\
\hline & Leaves & Stem & Total & $\mathrm{N}$ & $\mathrm{P}$ & K & $\mathrm{Ca}$ & $\mathrm{Mg}$ & $\mathrm{Al}$ & B & $\mathrm{Fe}$ & $\mathrm{Mn}$ & Mo & $\mathrm{Na}$ & $\mathrm{Zn}$ \\
\hline 1.0 & $10.0 \mathrm{a}$ & $16.8 \mathrm{a}$ & $71.6 \mathrm{a}$ & 0.91 & 0.28 & 3.18 & 1.26 & 0.34 & 4.8 & 31 & 16 & 25 & 0.85 & 391 & 23 \\
\hline Control & 8.7 & 13.1 & 67.1 & 1.11 & 0.25 & 2.61 & 1.63 & 0.44 & 6.3 & 24 & 18 & 28 & 0.64 & 514 & 36 \\
\hline Stress & 8.0 & 12.5 & 63.4 & 1.32 & 0.23 & 2.71 & 1.61 & 0.46 & 5.2 & 25 & 20 & 30 & 0.60 & 449 & 37 \\
\hline \multicolumn{16}{|c|}{ F significance } \\
\hline $\mathrm{BD} \times \mathrm{S}$ & NS & NS & NS & $* *$ & NS & NS & NS & NS & NS & * & NS & NS & NS & NS & NS \\
\hline
\end{tabular}

${ }^{2}$ Trunk and root dry weight were not significant.

Ns,*,***Nonsignificant or significant at $P \leq 0.05$ or 0.01 , respectively.

Table 6. Interaction of soil bulk density and short-term moisture stress on leaf carbohydrates $\left(\mathrm{mg} \cdot \mathrm{g}^{-1} \mathrm{dry}\right.$ weight) of 'Chambourcin' grapevines.

\begin{tabular}{lcccccc}
\hline $\begin{array}{l}\text { Bulk } \\
\text { density } \\
\left(\mathrm{g} \cdot \mathrm{cm}^{-3}\right)\end{array}$ & $\begin{array}{c}\text { Moisture } \\
\text { stress }\end{array}$ & Fructose & Glucose & Myoinositol & Sucrose & Unknown \\
\hline 1.0 & Control & $229 \mathrm{a}^{\mathrm{z}}$ & $112 \mathrm{a}$ & $64 \mathrm{~b}$ & $83 \mathrm{a}$ & $39 \mathrm{~b}$ \\
1.0 & Stress & $138 \mathrm{~b}$ & $63 \mathrm{~b}$ & $43 \mathrm{c}$ & $22 \mathrm{~b}$ & $33 \mathrm{~b}$ \\
1.5 & Control & $185 \mathrm{a}$ & $116 \mathrm{a}$ & $74 \mathrm{a}$ & $93 \mathrm{a}$ & $40 \mathrm{~b}$ \\
1.5 & Stress & $206 \mathrm{a}$ & $126 \mathrm{a}$ & $75 \mathrm{a}$ & $28 \mathrm{~b}$ & $70 \mathrm{a}$ \\
\hline
\end{tabular}

${ }^{2}$ Means separated by LSD 0.05 .

significant increases only in leaf $\mathrm{P}, \mathrm{K}, \mathrm{B}$, and Fe (Ferree et al., 2003). Shierlaw and Alston (1984) suggest that inhibition of root elongation is not necessarily correlated with inhibited uptake of mineral nutrients because contact between roots and soils increases in compacted soils.

In general, the impact of treatments on carbohydrate composition of leaves (Table 6) closely reflected the impact of treatments on photosynthesis. That is, photosynthetic activity was depressed 8-fold under moisture stress and moisture stress also substantially depressed carbohydrate concentrations. However, under high soil compaction, only sucrose concentration was depressed(Table 5); the lack of moisture on other carbohydrates is difficult to explain.

Several investigators (Hussain et al., 1999; Masle and Passioura, 1987; Mulholland et al., 1996) suggest that root-derived hormonal signals were likely responsible for the growth reductions caused by soil compaction. Plant hormones were not investigated in the presented series of studies. However, we did demonstrate that under greenhouse container conditions, growth of grapevines was reduced with increasing levels of soil compaction. A soil bulk density of 1.5 $\mathrm{g} \cdot \mathrm{cm}^{-3}$ consistently reduced shoot growth of grapevines and in one or more studies reduced average leaf area, number of flower clusters and advanced bloom. A comparison of the growth of grapevines on five rootstocks compared to own rooted vines provided no indication that a difference in response to soil compaction existed among rootstocks. The large leaf areas on the vines used in these studies quickly resulted in moisture stess when water was withheld and moisture stress was delayed in compacted soils. Generally, there was no interaction between soil compaction and moisture stress except for leaf carbohydrate distribution. The growth reduction caused by soil compaction did not appear to be due to nutrient uptake or distribution of leaf carbohydrate fractions.

\section{Literature Cited}

Andrade, A., D.W. Wolfe, and E. Fereres. 1993. Leaf expansion, photosynthesis and water relations of sunflower plants grown in compacted soil. Plant Soil 149:174-184.

Brereton, J.C., M. McGowan, and T.C.K. Dawkins. 1986. The relative sensitivity of spring barley, spring field beans and sugarbeets to soil compaction. Field Crops Res. 13:223-232.

Cahoon, G.A. 1985. Fertilizing fruit crops. Ohio Coop. Ext. Serv. Bul. 458 p.22.

Conlin, T.S.S. and R. van den Driessche. 1996. Short term effects on soil compaction on growth of Pinus contorta seedlings. Can. J. For. Res. 26:727-739.

Eichhorn, K.W. and D.H.Lorenz. 1977. Phanologische entwicklungsstadien der rebe, Nachsfenhtenbl. Dtsch. Pflanzenschutzdienstes (Braunschweig) 29:119-120.

Ferree, D.C., G.A. Cahoon, M.A. Ellis, D.M. Scurlock, and G.R. Johns. 1996. Influence of eight rootstocks on the performance of 'White Riesling' and 'Cabernet Franc' over five years. Fruit Var. J. 50:124-130.

Ferree, D.C., J.G. Streeter, and Y. Yuncong. 2003. Response of container grown apple trees to soil compaction. HortScience 39:40-48.

Gross, M.J. 1977. Effects of mechanical impedance on root growth in barley. I. Effect on the elongation and branching of seminal root axes. J. Expt.
Bot. 28:96-111.

Hussain, A., C.R. Black, L.B. Taylor, B.J. Mulholland, and J.A.Roberts. 1999. Soil compaction. A role for ethylene in regulating leaf expansion and shoot growth in tomato. Plant Physiol. 121:1227-1237.

Masle,J.and G.G.Farquhar. 1988. Effect of soil strength on the relation of water use efficiency and growth to carbon isotope discrimination in wheat seedlings. Plant Physiol. 86:32-38.

Masle, J. and J.B. Passioura. 1987. The effect of soil strength on the growth of young wheat plants. Austral. J. Plant Physiol. 14:643-656.

Maupin, C. andD.K. Struve. 1997. Redoaktransplanted todifferentbulk density soils have similar water use characteristics. J. Arboricult. 23:233-238.

Mulholland,B.J.,C.R.Black,L.B.Taylor,J.A. Roberts, and J.R. Lenton. 1996. Effect of soil compaction on barley (Hordeum vulgare L) growth. I. Possible role for ABA as a root- sourced chemical signal. J. Expt. Bot. 47:539-549.

Myburgh, P., A. Cass, and P. Clingeleffer. 1998. Root systems and soils in Australian vineyards and orchards-An assessment. 1996 Brossa Valley Rotary Found. Fellowship Rpt. p. 28.

Penkov, M., R. Nancheva, D. Hristova, and H. Etropolski. 1979. The effect of bulk density on the position of the grapevine root system (Bulgarian) PochvoznanseiAgrokhimiya 14:24-27(Hort.Abst. 50:8891; 1980).

Shierlaw, J. and A.M. Alston. 1984. Effect of soil compaction on root growth and uptake of phosphorus. Plant Soil 77:15-28.

Slowik, K. 1970. Influence of machinery compaction on soil physical properties and apple tree growth. (English summary). Prace Instytutu Sadonictiwa W. Skierniewicach Tom XIV P. 140.

Streeter, J.G. and C.E. Strimbu. 1998. Simultaneous extraction and derivatization of carbohydrates from green plant tissues for analysis by gas-liquid chromatography. Anal. Biochem. 219:253-257.

Van Huyssteen, L. 1989. Quantification of the compaction problem of selected vineyard soils and a critical assessment of methods to predict soil bulk density from soil texture. PhD diss. Agr. (Soil Sci.) Univ. Stellenbosch.

Vepraskas, M.J. 1994. Plant response mechanisms to soil compaction, p. 263-287. In: R.E. Wilkinson (ed.). Plant-environment interactions. Marcel Dekker, Inc., New York.

Watson, M.E. and R.A. Isaac. 1990. Analytical instruments for soil and plant analysis, p. 691-740. In: R.L. Westerman (ed.). Soil testing and plant analysis. Soil Sci. Soc. Amer. Madison, Wis.

Table 7. Soil penetrometer values (Kpa) taken in containers in the level of compaction and compaction short-term moisture stress studies.

\begin{tabular}{|c|c|c|c|c|c|c|c|c|c|}
\hline \multirow{2}{*}{$\begin{array}{l}\text { Depth } \\
(\mathrm{cm})\end{array}$} & \multicolumn{7}{|c|}{ Soil bulk density $\left(\mathrm{g} \cdot \mathrm{cm}^{-3}\right)$} & \multicolumn{2}{|c|}{ Moisture treatment } \\
\hline & 1.0 & 1.2 & 1.3 & 1.4 & 1.5 & 1.0 & 1.5 & Control & Stress \\
\hline $6-10$ & $985 \mathrm{c}$ & $2370 \mathrm{~b}$ & $2177 \mathrm{~b}$ & $2928 \mathrm{~b}$ & $4326 \mathrm{a}$ & $232 \mathrm{~b}$ & $2230 \mathrm{a}$ & $1116 \mathrm{a}$ & $1447 \mathrm{a}$ \\
\hline
\end{tabular}

${ }^{2}$ Mean separation in rows by Duncan's multiple range test $P=0.05$. 